\title{
Willingness to pay for ecosystem conservation in Alaska's Tongass National Forest: a choice modeling study
}

\author{
Evan E. Hjerpe ${ }^{1}$ and Anwar Hussain ${ }^{1,2}$
}

\begin{abstract}
Forest ecosystems contribute to human welfare in important ways, but because of the nonmarket nature of many of the goods and services produced, both markets and governments fail to optimize their production commensurate with their economic and ecological significance. Despite the recent proliferation of nonmarket environmental valuation in the literature, the incorporation of nonmarket values into public forest decision making has been limited by institutional and methodological barriers. To address this disconnect, we conducted a case study to quantify conservation values for the Tongass National Forest in a manner conducive for public forest planning. A choice experiment featuring proposed forest management alternatives with changes in critical attributes relative to their levels in the status quo was used to generate the requisite data. Econometric analysis suggests that Alaskans have strong preference for conservation management, including both preservation and ecological restoration, over status quo or exploitation management. However, there is significant heterogeneity among Alaskans in terms of bias toward the status quo depending on their socioeconomic characteristics, e.g., gender, age, place of residence, household income, whether or not they have dependent children. The findings of this study can be helpful to forest managers in the preparation of resource management plans consistent with maximization of total economic value of forest ecosystem services.
\end{abstract}

Key Words: choice experiment; conservation economics; ecological restoration; nonmarket valuation; old-growth forests; Tongass National Forest

\section{INTRODUCTION}

Old-growth forests are both ecologically and economically important. Forests that have not experienced industrial logging, commonly called "old-growth" forests, ${ }^{[1]}$ offer unique levels of ecosystem services to society, particularly in providing high quality fish and wildlife habitat, clean water, scenic beauty, and carbon storage that have led to calls for old-growth conservation (Thomas et al. 1988, Luyssaert et al. 2008, DellaSala et al. 2011). Old-growth forests in the U.S. are becoming a scarce commodity, as remaining old-growth stands are now generally confined to stunted, higher-elevation forests and pockets of protected areas (Spies and Duncan 2009). An exception to this is the remaining coastal rainforest old growth in Southeast Alaska and the Tongass National Forest (hereafter the Tongass), the largest national forest in the U.S. Although most of the 17 million acre Tongass is rock, ice, or unproductive forests, ${ }^{[2]}$ there are many productive oldgrowth stands covering salmon-filled watersheds. About a million acres of the most productive old-growth forests in southeast Alaska have already been clear-cut when including both Native Corporation and National Forest logging, and another half million acres of old growth are scheduled for future harvest on the Tongass (TLMP 2008). As such, the Tongass timber program is the last industrial-scale, old-growth logging program in the U.S.

Given the national scarcity of old-growth forests and their importance, ecosystem conservation efforts are being developed in Southeast Alaska via collaborative planning between the U.S. Forest Service (USFS), nongovernmental organizations, Native Alaskan tribes, and communities. Because commercial timber harvest and logging roads in the past six decades have had adverse effects on forest resources, conservation efforts include plans for both preserving existing old-growth and restoring adjacent, cutover forests and degraded salmon streams. Proposed Tongass conservation programs are not intended to end all Tongass logging because Tongass timbering jobs can be an important source of economic development for some communities. Rather, stakeholders and the USFS are looking to increase conservation efforts while transitioning the timber harvest out of old-growth watersheds, into cut-over second-growth watersheds (USDA News Release 2010).

The economic rationale for the Tongass timber program is primarily one of job creation, that is, maintaining social development in remote parts of Alaska (TLMP 2008, Hjerpe 2011). The market impacts of the Tongass timber program, in terms of board feet of production and regional employment, are well monitored and incorporated into USFS planning processes despite representing less than $1 \%$ of regional employment (Hjerpe 2011). However, the economic values foregone by clear-cutting old growth, are noticeably absent from the planning process. Because the values for old-growth ecosystem services heavily comprise nonmarket values, direct survey and other nonmarket methods are required to determine the extent of these values. This type of research has not been conducted on the Tongass; without the inclusion of conservation values, land management planning on the Tongass is skewed toward timber production (Loomis 1987).

Missing conservation values on the Tongass are emblematic of economic valuation problems encountered in most public forest planning. In the U.S., all public land management agencies, including the USFS, have struggled to consistently incorporate the largely nonmarket values that compose conservation values into land management planning (Kline et al. 2013). When conservation values are incorporated, the USFS has typically only incorporated use values of recreation (consumer surplus), generally bypassing passive use values (Loomis and Walsh 1992). This failure to internalize conservation benefits into the national 
forest planning process (Morton 1999) is a result of both institutional and valuation barriers and is directly at odds with recent advancements of nonmarket and ecosystem service valuation in the literature. Economic studies of conservation values, primarily using stated preference methods, have proliferated in the last couple of decades. But the refinements have been largely theoretical, with little exploration of the applicability of nonmarket valuation to policy formation.

To address the disconnect between advancements in academic environmental economics and the lack of inclusion of nonmarket values in public forest management, we assessed the literature and conducted a case study to quantify conservation values in a manner conducive for decision making. We designed a choice experiment to quantify the economic value of old-growth preservation on the Tongass in management units that can be used as either positive welfare gains to society when conservation programs are analyzed, or as opportunity costs per acre of old growth scheduled for harvest. Our choice of attributes, our use of absolute measurements in conservation units, our framing of choices within actual management prescriptions and administrative boundaries, and our description and offering of a status quo option were deliberately conducted to maximize the application of our findings. This overall approach is unique in the literature and we hope to contribute to a greater dialogue addressing the lack of conservation values in USFS planning calculus.

\section{Background}

The complexity of nonmarket valuation has contributed to its limited use in public forest planning, but a number of institutional barriers also limit the adoption and incorporation of conservation values. These institutional barriers include limited economics capacity within the USFS particularly at regional and forest planning levels (Bowes and Krutilla 1989, Morton 1999, Kline et al. 2013) and planning budgets often dominated by a timber production focus that leaves little room for research on conservation values. In timber-dominated regions, such as the Tongass, USFS managers have an incentive to prioritize local economic stability, to conduct even-aged management (clearcutting), and view timber harvest as the best way to enhance other multiple uses (Sabatier et al. 1995). The resulting excessive subsidies, below-cost timber sales, and other socially inefficient outcomes on these national forests are the likely result of budgetmaximization hypothesis (O'Toole 1988) and inertia from many years of timber investments. Collectively, a lack of economics capacity and timber-centric budgets are institutional barriers that lead to land management planning that is inflexible to assessing and incorporating conservation values.

Issues in economic valuation methodologies provide additional barriers to widespread implementation of conservation values in public forest planning. For stated preference methods, such as contingent and conjoint analyses, primary methodological issues center on the validity and reliability of estimates because of the subjective nature of hypothetical markets and passive use values. These issues of validity received great attention once simulated markets were being used to measure, and pay out, lost passive use values stemming from the Exxon Valdez oil spill case and other natural resource damage assessments (Arrow et al. 1993, Hausman 1993). Since then there has been tremendous advancements in the literature tackling each methodological concern. Many empirical results have illustrated that willingness to pay estimates have been consistent with estimates from other methods (convergent validity), typically accord with economic theory and predictors (construct validity), and are generated from studies increasingly incorporating best practices (content validity; Freeman 2003). The evolution from contingent valuation to conjoint analyses, such as choice experiments, has further reduced concerns of hypothetical bias by better framing substitution effects for participants and reducing scope concerns of participants not being able to distinguish between varying amounts and intensities of conservation (Boxall et al. 1996, Hanley et al. 1998). When estimated properly, the reliability of contingent valuation estimates, at least in the economics literature, is no longer a concern (Boyle 2003). Whether this consensus of reliability translates to forest managers or to proponents of extractive uses, is a different but important matter, and a justification for our case study.

Although inconsistencies in stated preference results can provide valuation barriers, many of the methodological concerns about incorporating willingness to pay estimates into planning are of no greater concern than methodological issues of economic methods already widely incorporated in USFS forest planning. Issues with economic impact analyses of jobs and income and their associated multiplier effects, along with the limitations of linear programming models such as FORPLAN and SPECTRUM are of equal concern in the accuracy and reliability of modeling outputs used and generated at the forest level. The linear programming models used to schedule timber harvests optimize objective functions given a set of constraints. Linear programs do not provide guidance on which objective functions provide the greatest societal welfare; rather they optimize the primary objective chosen. The result has been that the primary objective is a commodity focus such as maximizing the net present value of future timber harvests, where conservation goals are simply entered as constraints (e.g., Endangered Species Act requirements and Wilderness area acreage). The resulting modeler bias, along with spatial limitations and missing biophysical response measurements make linear programming models incapable of capturing the total economic value of management decisions (Morton 1999) and have contributed to a publicly perceived "black box" approach to forest management (de Steiguer et al. 2003).

Economic impact analyses included in USFS land management plans also suffer from major methodological concerns. Impact analyses are typically conducted with off-the-shelf input-output models such as IMPLAN. These input-output models are predicated on economic base theory that presumes that regional economic activity can be separated into basic (export) and nonbasic (infilling services) industries, with basic activities determining the extent of nonbasic activities. Yet, in one of the few recent empirical attempts to validate these assumptions, Robertson (2003) found that these assumptions did not hold for the timber industry in Southeast Alaska and the Tongass. Other assumptions of IMPLAN, such as static economies and technology, limit their utility in projecting economic impacts into the future or for the duration of a forest planning cycle. The economic theory behind the illustration of distributional economic impacts, such as jobs and income associated with a 
particular forest management alternative, are no more understood by forest managers, or of less concern, than theories supporting nonmarket valuation.

\section{Literature review}

Forest ecosystems provide myriad goods and services. However, in the context of economic valuation they are only goods and services if they are beneficial to humans in some sense, e.g., use, option, bequest, existence values. The broader notion of total economic value (TEV) captures these use and passive use values, and has beneficial implications for guiding forest management policies (Loomis and Walsh 1992, Bann 2002). According to TEV, individuals can hold multiple values for ecosystems and TEV can be used to categorize these various benefits (Heal et al. 2005). If economic values for conservation, and the public's marginal willingness to pay for conservation, are not estimated in this manner, many of the major benefits of ecosystems will continue to be excluded in benefit-cost computations. The likely outcome of such an omission is too little protection for ecosystems, and as a consequence the majority of services that people directly and indirectly consume are undersupplied.

Interest in economic valuation consistent with TEV has taken center stage in applied economics research, culminating in improved integration of the disciplines of ecology and economics, and widespread use of multiattribute valuation methods germane to issues in the two disciplines, e.g., biodiversity valuation, old growth preservation, ecological restoration. Although the basis for TEV analyses of ecosystem conservation, including the critical development of passive use values, was formed earlier (CiriacyWantrup 1952, Weisbrod 1964, and Krutilla 1967), Mitchell and Carson's (1989) text on valuing public goods with contingent valuation spurred numerous TEV studies associated with conservation. As more contingent valuation studies were conducted, Walsh et al. (1990) found that public preservation values, or passive use values, composed nearly $75 \%$ of total economic value and Loomis (2000) found passive use values dominated TEV. The NOAA blue ribbon panel (Arrow et al. 1993) helped contingent valuation gain further legitimacy and since then, the development of stated preference methods has exploded. With the recent evolution in USFS management paradigms to ecosystem management and now ecosystems services, incorporating stated preference methods is the most comprehensive way of providing holistic values for entire land management plans or desired future conditions of landscapes (Loomis 2012). Of the stated preference techniques, the use of attribute-based methods provides a richer basis for benefit-cost analysis of management strategies and implicit economic tradeoffs between management attributes (Holmes and Adamowicz 2003).

A recent meta-analysis (Hjerpe et al. 2015) of international willingness to pay for ecosystem conservation on public lands found strong economic value for forest preservation, watershed restoration, and forest restoration. Reviewing the 22 primary studies included in the meta-analysis, however, shows that the attributes offered to survey participants were rarely in the form of landscape units appropriate for planning. Most attributes consisted of individual outputs that would change as a result of the preservation or restoration program implemented such as individual species population numbers, levels of biodiversity, pollution levels, or individual ecosystem services. Focusing on individual species and outcomes of conservation in the attributes, as opposed to focusing on the entire conservation program, underestimates the total economic value of programs by missing out on the complementary and super-additivity nature of holistic conservation (Loomis and White 1996, Holmes et al. 2004). Perhaps even more importantly, the application of willingness to pay for individual outcomes of conservation requires greater translation and interpretation by public land managers that may want to incorporate these values. The provision of tangible landscape conservation metrics in the attributes allows for greater ease in using conservation values to inform land management planning by being directly incorporated and offering greater marginal analysis of partial conservation alternatives (Hanley et al. 1998, Loomis 2012).

A few studies are notable for including use and passive use values of conservation in manners more compatible with planning processes. Garber-Yonts et al. (2004) provide perhaps the most complete set of conservation values in terms of management applications, using a choice experiment to estimate public willingness to pay for increasing endangered species habitat, salmon and aquatic habitat protection, old-growth forest preservation, and large-scale nature reserves as a means to inform biodiversity conservation policies in Oregon. Adamowicz et al. (1998) examined use and passive use values by estimating willingness to pay for woodland caribou habitat enhancement and focused on attributes of caribou populations and wilderness area. Lehtonen et al. (2003) estimated Finnish citizens' values for conservation programs and included conservation contracts and areas as attributes.

A few important insights emerge from the literature on conservation economics and public forest planning. First, it is clear that people value forests for much more than just timber production and logging jobs. Second, despite the complexity of ecosystems and the contingent nature of nonmarket valuations, it is possible to meaningfully engage the general public in informing forest management policies. Finally, the majority of refinements in total economic valuation of conservation have been necessarily theoretically focused, with little attention being paid to the applicability of results for land planning.

Disaggregating public lands policies into appropriate characteristic sets and levels for applied choice modeling is a difficult task (Hanley et al. 1998). To address the limited attention to applicability in the literature, we propose a few best practices for mainstreaming conservation values into public lands management: (1) Incorporate stated preference methods, and particularly the family of attribute-based methods such as choice experiments, because they offer the most comprehensive format for accounting for both use and passive use values associated with conservation (e.g., Freeman 2003, Holmes and Adamowicz 2003, Banzhof 2010); (2) Focus attributes on management alternatives as opposed to individual or social outcomes (Loomis 2012); (3) Offer attributes in absolute landscape metrics such as acres preserved or river miles restored allowing for marginal valuation across management alternatives (Hanley et al. 1998, Loomis 2012); (4) Align choice alternatives and attributes within the same administrative and political boundaries when feasible ${ }^{[3]} ;(5)$ Provide spatially explicit and exclusive alternatives and attributes 
(Loomis 2012); (6) Consider the bundle of ecosystem services offered in attributes and try to offer management attributes that affect those bundles in similar directions; And finally, (7) include a status quo alternative at zero cost that represents an extension of current management or a No Action alternative.

\section{METHODS}

A choice experiment was designed, pretested, and administered to Alaskan households. The focus of the choice experiment was to elicit public values held for proposed Tongass conservation programs. Best practices for choice experiment design and management application, as synthesized from the literature, were incorporated. Detailed statistical estimation procedures are described below.

\section{Study area}

The focal point of the choice experiment was to determine the public willingness to pay for conservation programs in the most productive watersheds in the Tongass. The Tongass spans much of Southeast Alaska and is almost 17 million acres; but more than $40 \%$ of the Tongass is rock, ice, muskeg, or water. Of the 10 million forested acres in the Tongass, the majority is considered unproductive for timber production purposes because of the slowgrowing, lightly stocked forests that result from exposure to alpine conditions and poorly drained soils. About three million acres are mapped as available for harvest, with one million acres mapped as suitable for harvest including many acres of already harvested forests (TLMP 2008). These one million acres of "suitable" timber generally represent the most productive forests on the Tongass, both for timber production and biological production. These acres, comprising 445,000 acres of remaining old growth scheduled for harvest and another half million acres that have already been harvested (second growth), were the specific areas within the Tongass that respondents were asked about. The study area is shown in Figure 1.

Fig. 1. Tongass National Forest in Southeast Alaska.

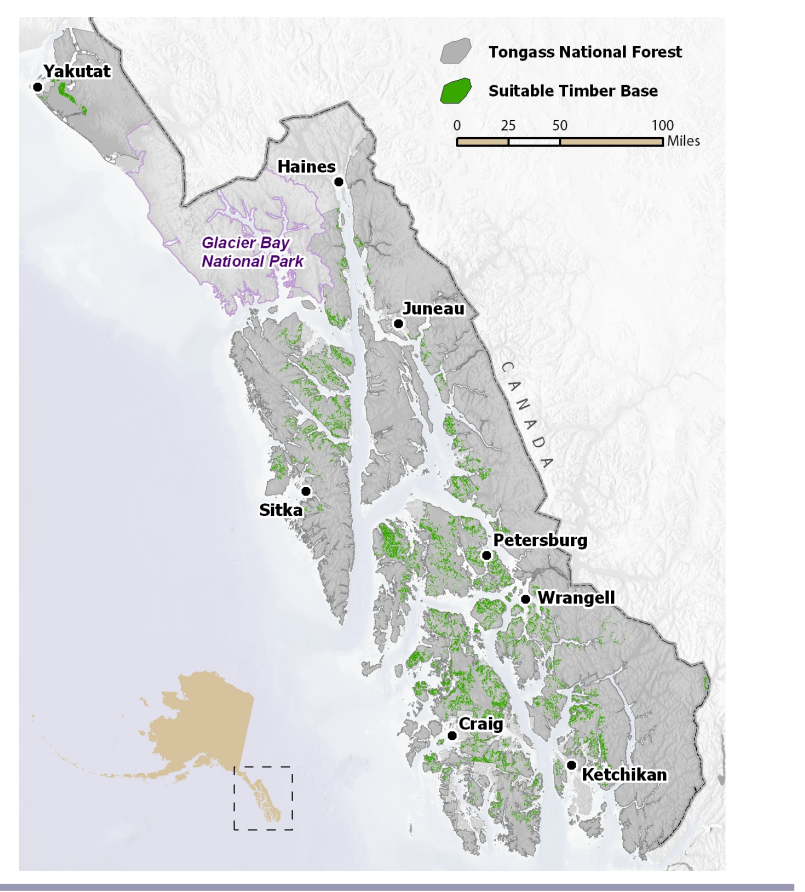

\section{Choice experiment design}

Based on discussions with scientists, forest managers, and stakeholder focus groups in Alaska, three management alternatives for the Tongass were designed. Two of the alternatives focused on improved levels of conservation involving preservation of old-growth forest, and restoration of degraded watershed streams (measured in miles) and acres of second-growth forest. The third alternative characterized the status quo situation of continued clear-cutting of old-growth forests and minimal restoration of watershed streams and second-growth forest.

All alternatives contained the following four attributes: amount of old growth conservation, stream restoration, second-growth forest restoration, and a one-time contribution by households to a Tongass conservation fund. Three levels were assigned to each attribute because preferences for ecosystem services are expected to be curvilinear (implying nonlinear marginal utilities for ecosystem services). These levels were expected to encompass the range of potential outcomes that could result from the proposed conservation programs. Table 1 provides more details about the attributes and their levels.

\section{Attribute descriptions}

We describe the conservation program attributes, how changes in the attributes may lead to changes in ecosystem service production, opportunity costs, and why Alaskan households might be willing to pay for them. The description is consistent with attribute portrayal to respondents in the choice experiment survey. The survey presented the information in a nontechnical manner, e.g., no references, summarizing the issue and potential solutions.

\section{Old-growth conservation}

The most economically valuable old-growth acres in the forest (470,000 acres) have already been logged, and the current Tongass management plan has another 445,000 acres of some of the most productive, remaining old-growth watersheds scheduled for harvest. This Tongass old growth is critically important in the production of biological regulation (Person et al. 1996), climate regulation (Leighty et al. 2006), biodiversity refugia (e.g., Cotter and Kirchoff 2007), and numerous cultural and recreational services. Because it takes centuries to develop the biological characteristics of old growth, the management alternatives in the choice experiment offered the conservation of up to 445,000 acres of old growth scheduled for harvest (all old growth scheduled for harvest). Preserving old-growth watersheds would maintain the ecological integrity of the forest for present and future generations and provides the greatest insurance, because restoration efforts can never fully replicate the original, pristine conditions of wild and untrammeled ecosystems. However, increases in this attribute would come with opportunity costs because it would decrease the amount of trees available for logging and limit the available areas for road, mineral, and energy development.

\section{Stream Restoration}

Poor stream habitat in the Tongass has been shown to be a significant cause of wild salmon species decline below their historical levels and diminished aquatic health (Heifetz et al. 1986, Stillwater Sciences 2012). Logging and road building in the past six decades in the forest have contributed to the problem by (a) increasing soil erosion; (b) decreasing streamside trees needed by fish; and (c) blocking fish passages used by salmon to migrate to 
Table 1. Definitions of variables used in the econometric analysis.

\begin{tabular}{|c|c|}
\hline Variable & Description \\
\hline Dependent Variable & Discrete choice between conservation Alternative A, B, and Status Quo \\
\hline \multicolumn{2}{|r|}{ 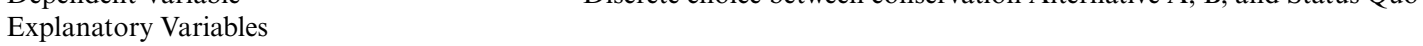 } \\
\hline \multicolumn{2}{|l|}{ Alternative-specific attributes } \\
\hline Old growth forest conservation & $(\%$ of 445,000 acres to be conserved $) ;$ Levels $=0 \%, 50 \%, 100 \%$ \\
\hline Second growth forest restoration & $(\%$ of 100,000 acres to be restored); Levels $=0 \%, 50 \%, 100 \%$ \\
\hline Watershed restoration & $(\%$ of 100 stream miles to be restored $)$, Levels $=0 \%, 50 \%, 100 \%$ \\
\hline Cost to the household ${ }^{\dagger}$ & US dollars; Levels $=\$ 30, \$ 75, \$ 100$ \\
\hline \multicolumn{2}{|l|}{ Household characteristics } \\
\hline Gender & Dummy $=1$ if male, else 0 \\
\hline \multicolumn{2}{|r|}{ Lentimg } \\
\hline Age $<45$ & Dummy $=1$ if respondent age less than 45 years, else 0 \\
\hline Age 45 to 60 & Dummy $=1$ if respondent age between 45 and 60 years, else 0 \\
\hline Age $>60$ & Dummy $=1$ if respondent age greater than 60 years \\
\hline \multicolumn{2}{|l|}{ Household Income } \\
\hline Income: $<50 \mathrm{~K}$ & Dummy $=1$ if household income is less than $\$ 50,000$, else 0 \\
\hline Income: 50 to $100 \mathrm{~K}$ & Dummy $=1$ if household income is $\$ 51,000$ to 100,000 , else 0 \\
\hline Income: > $100 \mathrm{~K}$ & Dummy $=1$ if household income is more than $\$ 100,000$, else 0 \\
\hline Household residence & Dummy $=1$ if household lives in Southeast Alaska, else 0 \\
\hline Dependent children & Dummy $=1$ if household has dependent children age 18 years or less \\
\hline
\end{tabular}

spawning locations (Dunlap 1997). River and stream degradation stemming from timber production adversely affect many other ecosystem services, beyond those just associated with consuming, viewing, or knowing that wild salmon exist in historically abundant levels. For example, documented examples on the Tongass include the degradation of nutrient cycling (Tiegs et al. 2008), water regulation (Gomi et al. 2004), and erosion control services (K. Kahklen and W. Hartsog 1998, unpublished manuscript).

Stream restoration includes placement of large downed wood, creation of pools, bank stabilization, culvert replacement, riparian thinning, and road decommissioning. With approximately 500 miles of degraded streams (USFS 2006), current Tongass management plans target only about $5 \%$ of these stream miles for restoration activities (attribute level in the status quo alternative). Alternately, the conservation alternatives in the choice experiment allowed respondents to value the restoration of up to 100 miles of prioritized degraded streams. Investments in restoration activities have been shown to improve the aquatic health of degraded streams by improving soil stability, water quality, and aquatic habitat for fish and invertebrates (Keeley et al. 1996). Watershed restoration also generates engineering and environmental consulting jobs.

\section{Second-growth forest restoration}

Decades of logging in the Tongass have left 470,000 acres in degraded conditions along with miles of abandoned timber roads that contribute to erosion. The second-growth trees that follow logging are too dense to produce the natural amount of grasses and berries that are critical to wildlife (Wallmo and Schoen 1980). This impaired state has persisted for well over 100 years (Alaback 1982). Primary affected ecosystem services include the degradation of wildlife habitat (e.g., Kirchoff and Schoen 1987,
Flatten et al. 2001), decreased carbon storage (Leighty et al. 2006), and degraded disturbance regulation (Harris 1999). The degradation of these services also has cascading adverse effects on numerous cultural and provisioning ecosystem services directly and indirectly associated with these forests.

Forest restoration includes variable density thinning of trees (as opposed to even-spaced plantation thinning) and can improve understory production, native biodiversity, and speed the successional trajectory to old-growth conditions (Christensen 2012). Forest restoration in the Tongass would also generate employment opportunities and woody by-products (Hjerpe 2011). According to the current Tongass management plans, about $1 \%$ of the second growth acres are targeted for restoration activities (attribute level in the status quo alternative). In contrast, the proposed conservation management plans offered to respondents in the choice experiments allowed for the restoration of up to 100,000 acres of prioritized second growth (out of 470,000 acres).

\section{Survey administration}

Because Alaskans have varying levels of knowledge about the Tongass, the set of attributes and their levels were explained to respondents. The attributes addressed conservation objectives in a meaningful and implementable way, and how important they were to respondents in terms of their use values, passive use values, and opportunity costs. The information about the selected conservation attributes and their levels formed the basis for the creation of orthogonal choice sets. Using SAS experimental design procedures, four attributes with three levels each were used to create 32 alternative choice sets. Because processing information about 32 choice sets is an enormous task, the 32 choice sets were randomly divided into 8 blocks of 4 choice sets each. In effect, each respondent was asked to choose the most 
preferred option from each of the 4 choice sets, as well as rank them. A sample choice set administered to Alaskan households is given in Appendix 1. As the choice set shows, discrete choice as well as ranking data were generated. In the interest of brevity we analyze only the discrete choice data. To ensure that the survey would realistically elicit data of interest from respondent households, a pretest was carried out. Modifications to the questionnaire were made following the pretesting phase.

Each choice set included a status quo alternative whereby the current level of management (and thus, the current quantity and quality of derived ecosystem services) were assumed to continue over the next five years at no extra cost to the respondents, and two conservation alternatives requiring respondents to pay a onetime lump sum amount in return for ecological improvements over and above what could be achieved under the status quo. The inclusion of the status quo alternative allowed stakeholders adversely affected by conservation alternatives to reject any pair of alternatives in case they choose to do so. Note that the conservation alternatives were not labeled; the selected attributes and levels were assumed to communicate all the relevant information. Changes in attribute levels were communicated to respondents by measuring them relative to their levels in the status quo alternative.

The sample frame for the study consisted of Alaskan households. An introductory section explained the context in which choices were to be made, including cheap talk scripts that described hypothetical bias and the need to consider personal budgetary thresholds. Respondents were informed that completion of the exercise would help policy makers in prioritizing management strategies. Following the pretest, a sample of households was randomly drawn based on their willingness to participate in a web-based survey. To maximize response rate and induce respondents to answer all questions, 10 prizes amounting to $\$ 100$ each were promised and eventually given to randomly selected respondents. A follow-up telephone survey of a random subsample of nonrespondents was undertaken after the survey close-off date to find reasons for nonresponse.

\section{Willingness to pay estimation}

Given the multiattribute nature of current and proposed forest management alternatives in our research, we used a choice experiment. To obtain parameter estimates, the data were dummy coded. Three alternative models including conditional logit, nested logit, and random parameter logit were estimated using NLOGIT 4. Choice experiments generate a rich level of statistical information by allowing researchers to describe complex scenarios and trade-offs, and focus on more than one trade-off simultaneously. By incorporating the cost of implementing the proposed management alternatives as one of the attributes, parameter estimates from probabilistic choice models can be converted into willingness-to-pay estimates for changes in attribute levels (Adamowicz et al. 1998, Rolfe et al. 2000).

Random utility theory (McFadden 1974) provides the theoretical basis for analyzing and interpreting choice experiment data. According to this theory, the indirect utility function $\left(\mathrm{U}_{\mathrm{ij}}\right)$ for respondent $i$ who chooses alternative $j$ in the choice set can be expressed as the sum of a systematic $\left(\mathrm{V}_{\mathrm{ij}}\right)$ and random component $\left(\varepsilon_{\mathrm{ij}}\right)$ :

$$
U_{i j}=V_{i j}\left(X_{i j}, Z_{i}\right)+\varepsilon_{i j}
$$

The systematic component is typically specified as a function of the attributes of alternatives $\left(\mathrm{X}_{\mathrm{j}}\right)$ and respondent characteristics $\left(Z_{\mathrm{i}}\right)$. The random component $\left(\varepsilon_{\mathrm{ij}}\right)$ captures the influences of unobservable factors on individual's choice and allows probabilistic statements to be made about actual choices. Thus, let $\mathrm{U}_{\mathrm{ij}}$ be the utility individual $\mathrm{i}$ associates with alternative $j$. According to random utility hypothesis individual i will choose alternative $\mathrm{j}$ from choice set $\mathrm{C}_{\mathrm{i}}$ if and only if

$$
U_{i j}>U_{i k} \quad j \neq k \in C_{i}
$$

The probability that an individual $i$ will choose alternative $j$ rather than alternative $\mathrm{k}$ is given by

$$
\begin{aligned}
& P_{i j}= \\
& P\left(U_{i j}>U_{i k}\right)=P\left[V_{i j}+\varepsilon_{i j}>V_{i k}+\varepsilon_{i k}\right] \quad \forall j \in C_{i}
\end{aligned}
$$

\section{Conditional logit}

Assuming the random component of utility is independently and identically distributed across alternatives with extreme value type I distribution, the probability that individual i will choose alternative $\mathrm{j}$ from $J$ alternatives in choice set $\mathrm{C}_{\mathrm{i}}$ is given by (Greene 2008)

$$
P_{i j}=\frac{\exp \left(X_{i j}^{\prime} \beta\right)}{\sum_{j=1}^{J} \exp \left(X_{i j}^{\prime} \beta\right)}
$$

where $\beta$ are the parameters estimated using conditional logit. The systematic component may include the alternative specific constant (ASC), which can be manipulated to analyze endowment effect and interacted with individual-specific characteristics to account for preference heterogeneity (Adamowicz et al. 1998, Meyerhoff et al. 2009). The distribution assumption about the random component imposes the independence from irrelevant alternatives (IIA) restriction on the model. The restriction implies that cross-substitutions between pairs of alternatives are equal and unaffected by the presence or absence of other alternatives. When IIA is satisfied then the ratio of choice probabilities is not affected by whether another alternative is in the choice set or not.

\section{Nested logit}

To overcome the IIA restriction one option is to estimate a nested logit model, grouping similar alternatives into separate nests such that the random components are correlated within a nest of a choice set but not across nests. Let us divide the $\mathrm{J}$ alternatives into nonoverlapping branches with each branch containing $\mathrm{J}_{\mathrm{b}}$ alternatives. The nested logit probability $P_{i j b}$ is equal to the product of conditional probability of alternative $j$ in branch $b$ and marginal probability of branch $b$ That is,

$$
P_{i j b}=P_{i j \mid b} P_{b}
$$

where the first term on the right-hand side, $\mathrm{P}_{\mathrm{ijj} \mid \mathrm{b}}$ is the conditional probability that respondent $i$ chooses alternative (j) given that an alternative in branch $b$ is chosen whereas the second term is the marginal probability of choosing an alternative in branch $b$. Assuming that the error term in the respondent's utility function 
follows a generalized extreme-value distribution, the nested logit probability can be expressed as (Greene 2008)

$$
\begin{aligned}
& P_{i j b}= \\
& \frac{\exp \left(X_{i j \mid b}^{\prime} \beta\right)}{\sum_{j=1}^{J_{b}} \exp \left(X_{i j \mid b}^{\prime} \beta\right)} \frac{\exp \left[\tau_{b}\left(Z_{i b}^{\prime} \gamma+I V_{i b}\right)\right]}{\sum_{b=1}^{B} \exp \left[\tau_{b}\left(Z_{i b}^{\prime} \gamma+I V_{i b}\right)\right]}
\end{aligned}
$$

The coefficient $\tau$ is the inclusive value coefficient or dissimiliarity parameter (Ben-Akiva and Lerman 1985). The null hypothesis of the conditional logit model against the nested logit specification is $H_{o}: \tau=1$. Failure to reject this hypothesis means the nested logit collapses to conditional logit. Conversely, values significantly different from one justify nested logit structure. A global sufficiency condition for the nested logit model to be consistent with random utility maximization is that the parameter of inclusive value $(\tau)$ be in the range $0-1$ and not increase as we go to higher levels of the tree (Louviere et al. 2000).

\section{Random parameter logit ( $R P L)$}

In a random parameter logit model, the unknown parameters are assumed to be random, taking different values across the sampled respondents. The model is more general because it does not impose the IIA restriction at any level. According to RPL, the utility that individual $i$ derives from choosing alternative $j$ given by

$$
U_{i j}=\boldsymbol{\beta}_{k}^{\prime} X_{i j}+\mathbf{z}_{i}^{\prime} \boldsymbol{\theta}_{k}+\sigma_{k} u_{i k}+\varepsilon_{i j}
$$

where $\mathrm{u}_{\mathrm{ik}}, \mathrm{k}=1, \ldots ., \mathrm{K}$, is multivariate normally distributed with correlation matrix $\mathbf{R},{ }_{k}$ is the standard deviation of the $\mathrm{kth}$ distribution. Hensher et al. (2005) recommend constraining the distributions of the standard deviations when estimating the parameters is the mean of the distribution, $\mathbf{z}_{\mathrm{i}}$ is a vector of person specific characteristics that do not vary across choices, and $\varepsilon_{\mathrm{ij}}$ is a random term that is assumed to be independently and identically distributed extreme value. The parameters are estimated using simulated log-likelihood as the log-likelihood for the model cannot be solved analytically.

\section{Implicit prices and scenario willingness to pay}

Estimates of the coefficients of systematic component $\left(\mathrm{V}_{\mathrm{ij}}=\right)$ can be used to calculate willingness to pay (WTP) for improvements in utility as the difference between expected values of maximum utility after and before improvement, divided by the coefficient on cost variable $\left(\beta_{\mathrm{c}}\right)$, which proxies marginal utility of money. For changes in a single attribute $(x)$, marginal willingness to pay ( $\mathrm{mWTP}$ or implicit price) is given as:

$$
m W T P=-1\left(\frac{\beta_{x}}{\beta_{c}}\right)
$$

Marginal willingness to pay (mWTP) associated with changes in several attributes is

$$
m W T P=\frac{1}{\beta_{c}}\left[\ln \sum_{j=1}^{J} \exp \left(V_{j}^{1}\right)-\ln \sum_{j=1}^{J} \exp \left(V_{j}^{0}\right)\right]
$$

\section{EMPIRICAL RESULTS}

A survey research firm based in Anchorage, Alaska was contracted to administer the web-based survey from 9 April 2012 through 15 October 2012. A total of 1021 participants were recruited after making 61,260 phone calls in the state of Alaska. Participants were sent a personal message stating the purpose of the survey, the organization conducting it, and the estimated time required to complete the survey. In addition, the participants were told that of those who answer all survey questions, 10 will be randomly picked and given US\$100 each. By the end of the survey period 480 actually participated, with 384 of them answering all four discrete choice questions. A random sample of 20 of the nonrespondents was contacted to inquire about the reasons for not completing the survey. Most of the refusals were people who simply declined to participate and hung up without specifying a particular reason. The ones that did comment mentioned that they were not interested in the topic and/or uncomfortable giving out personal information. Considering the vast expanse of Alaska and issues with mailing, the web-based survey was the best option although over-representation of those with access to internet and computer literacy is possible and sample selection bias cannot be entirely ruled out.

\section{Descriptive statistics}

The analysis in this study is based on the responses of those 384 households that chose their favorite alternative from each of the four discrete choice sets. Of the three choice alternatives, the status quo alternative was chosen $24 \%$ of the time, whereas conservation alternative A was chosen $40 \%$ of the time and alternative B $36 \%$ of the time. Socioeconomic characteristics are reported in Table 2. A comparison with 2010 official statistics for Alaska from the U.S. Census Bureau shows over-representation of those over the age of 45 , those with greater education, and those dependent on forestry ( $14 \%$ of respondents reported some income from logging and wood products industries), and under-representation of those in income class less than $\$ 45,000$ and more than $\$ 100,000$. These departures from official statistics should be kept in mind when extrapolating results to the state level.

Table 2. Descriptive statistics of variables used in the econometric analysis.

\begin{tabular}{lcccc}
\hline \hline Variable & Mean & St. Dev & Min & Max \\
\hline $\begin{array}{l}\text { Frequency of Choice Alternatives } \\
\text { Conservation Alternative A (\%) }\end{array}$ & 0.40 & & & \\
$\begin{array}{l}\text { Conservation Alternative B (\%) } \\
\text { Status Quo (\%) }\end{array}$ & 0.36 & & & \\
& 0.24 & & & \\
Household characteristics & & & & \\
Gender & 0.55 & 0.49 & 0 & 1 \\
Age & & & & \\
Age $<45$ & 0.26 & 0.44 & 0 & 1 \\
Age 45 to 60 & 0.44 & 0.50 & 0 & 1 \\
Age $>60$ & 0.30 & 0.46 & 0 & 1 \\
Household residence & 0.58 & 0.49 & 0 & 1 \\
Household Income & & & & \\
Income: $<50 \mathrm{~K}$ & 0.23 & 0.42 & 0 & 1 \\
Income: 50 to 100 K & 0.37 & 0.48 & 0 & 1 \\
Income: $>100 \mathrm{~K}$ & 0.40 & 0.49 & 0 & 1 \\
Dependent children & 0.81 & 0.40 & 0 & 1 \\
\hline
\end{tabular}


Table 3. Estimation results of conditional logit, nested logit, and random parameter logit models.

\begin{tabular}{|c|c|c|c|c|c|c|}
\hline & \multicolumn{2}{|c|}{ Conditional logit } & \multicolumn{2}{|c|}{ Nested logit } & \multicolumn{2}{|c|}{ Random parameter logit } \\
\hline & Coeff (Std.Err) & $\mathrm{P}[|\mathrm{Z}|>\mathrm{z}]$ & Coeff (Std.Err) & $\mathrm{P}[|\mathrm{Z}|>\mathrm{z}]$ & Coeff (Std.Err) & $\mathrm{P}[|\mathrm{Z}|>\mathrm{z}]$ \\
\hline \multicolumn{7}{|c|}{ Alternative-specific Attributes } \\
\hline $50 \%$ acres & $0.475(0.079)$ & 0.000 & $0.247(0.049)$ & 0.000 & $0.508(0.095)$ & 0.000 \\
\hline $100 \%$ acres & $0.340(0.079)$ & 0.000 & $0.199(0.043)$ & 0.000 & $0.531(0.109)$ & 0.000 \\
\hline \multicolumn{7}{|l|}{ Watershed restoration } \\
\hline $50 \%$ miles & $0.301(0.077)$ & 0.000 & $0.192(0.041)$ & 0.000 & $0.438(0.092)$ & 0.000 \\
\hline $100 \%$ miles & $0.295(0.073)$ & 0.000 & $0.182(0.040)$ & 0.000 & $0.450(0.097)$ & 0.000 \\
\hline \multicolumn{7}{|c|}{ Second-growth forest restoration } \\
\hline $50 \%$ acres & $0.235(0.075)$ & 0.002 & $0.155(0.040)$ & 0.000 & $0.493(0.107)$ & 0.000 \\
\hline $100 \%$ acres & $0.210(0.075)$ & 0.005 & $0.125(0.040)$ & 0.002 & $0.336(0.093)$ & 0.000 \\
\hline \multicolumn{7}{|l|}{ Cost } \\
\hline Dollar cost & $-0.002(0.001)$ & 0.008 & $-0.001(0.001)$ & 0.066 & $-0.004(0.001)$ & 0.001 \\
\hline \multicolumn{7}{|c|}{$\begin{array}{l}\text { Standard Deviations of Random } \\
\text { parameters }\end{array}$} \\
\hline $50 \%$ acres & & & & & $1.015(0.190)$ & 0.000 \\
\hline $100 \%$ acres & & & & & $1.062(0.218)$ & 0.000 \\
\hline \multicolumn{7}{|l|}{ Watershed restoration } \\
\hline $50 \%$ miles & & & & & $0.876(0.183)$ & 0.000 \\
\hline $100 \%$ miles & & & & & $0.899(0.194)$ & 0.000 \\
\hline \multicolumn{7}{|c|}{ Second-growth forest restoration } \\
\hline $50 \%$ acres & & & & & $0.986(0.215)$ & 0.000 \\
\hline $100 \%$ acres & & & & & $0.672(0.186)$ & 0.000 \\
\hline \multicolumn{7}{|l|}{ Household characteristics } \\
\hline Gender & & & $0.743(0.135)$ & 0.000 & & \\
\hline Age 45 to 60 years & & & $-0.657(0.162)$ & 0.000 & & \\
\hline Age $>60$ years & & & $-0.167(0.162)$ & 0.303 & & \\
\hline Residence & & & $0.596(0.138)$ & 0.000 & & \\
\hline Income $\$ 50-100,000$ & & & $-0.725(0.163)$ & 0.000 & & \\
\hline Income $>\$ 100,000$ & & & $-0.650(0.172)$ & 0.000 & & \\
\hline HHs with children & & & $0.756(0.177)$ & 0.000 & & \\
\hline \multicolumn{7}{|l|}{ Dissimilarity Parameters } \\
\hline Conservation $\left(\tau_{1}\right)$ & & & $0.476(0.080)$ & 0.000 & & \\
\hline Status quo $\left(\tau_{2}\right)$ & & & 1.000 & Fixed & & \\
\hline \multicolumn{7}{|l|}{ Model statistics } \\
\hline Number of households & 384 & & 384 & & 384 & \\
\hline Number of choice sets & 1536 & & 1536 & & 1536 & \\
\hline Log-likelihood & -1620.267 & & -1567.100 & & -1587.921 & \\
\hline Hausman IIA test $(\tau=1)$ & 15.586 & 0.029 & & & & \\
\hline $\mathrm{AIC}$ & 2.119 & & 2.060 & & 2.077 & \\
\hline $\mathrm{BIC}$ & 2.143 & & 2.123 & & 2.101 & \\
\hline Pseudo R-Squared & 0.018 & & 0.099 & & 0.059 & \\
\hline
\end{tabular}

\section{Econometric results}

Based on the Hausman test, the null hypothesis of the independence from irrelevant alternatives (IIA) is rejected at the $5 \%$ level of significance $(\mathrm{p}=0.0292)$. Therefore, it is not appropriate to use conditional logit to analyze our data because the parameter estimates would be inconsistent. Partially relaxing IIA, a nested logit with two nests was estimated whereby the proposed alternatives were placed in one nest and the status quo alternative in the other. The inclusive value for the status quo alternative was constrained to 1 . The estimated value of unconstrained tau (inclusive value $=0.852$ ) is in the interval 0-1 and significant at $10 \%$, suggesting that using nested logit is appropriate for this data and in accordance with random utility hypothesis. Based on pseudo R-squared as well, the nested logit performs well compared with conditional logit and fits the data better. However, the log-likelihood at convergence and information criteria suggest that the more flexible random parameter logit, which does not impose IIA at any level and allows for preference heterogeneity, performs even better than nested logit. Thus, while results of conditional logit, nested logit, and random parameter logit are reported in Table 3, the rest of the article presents findings based on random parameter logit. 
Table 4. Marginal willingness to pay (mWTP) based on random parameter logit model, and state level extrapolated willingness to pay for Tongass conservation programs (2012 U.S. dollars).

\begin{tabular}{|c|c|c|c|c|c|c|}
\hline & \multicolumn{3}{|c|}{ Estimates $^{\dagger}$} & \multicolumn{3}{|c|}{ Extrapolated to the State ${ }^{\ddagger}$} \\
\hline & mWTP & Std Err. & $\mathrm{P}[|\mathrm{Z}|>\mathrm{z}]$ & Mean & Lower bound & Upper bound \\
\hline \multicolumn{7}{|l|}{ Attribute-specific } \\
\hline \multicolumn{7}{|c|}{ Old-growth conservation } \\
\hline $50 \%$ acres & 146.87 & 35.30 & 0.000 & $33,347,600$ & $25,332,000$ & $41,363,100$ \\
\hline $100 \%$ acres & 153.61 & 40.87 & 0.000 & $34,878,600$ & $25,597,400$ & $44,159,700$ \\
\hline \multicolumn{7}{|c|}{ Watershed restoration } \\
\hline $50 \%$ miles & 126.70 & 32.33 & 0.000 & $28,767,600$ & $21,426,200$ & $36,108,900$ \\
\hline $100 \%$ miles & 130.02 & 35.91 & 0.000 & $29,522,900$ & $21,369,800$ & $37,676,000$ \\
\hline \multicolumn{7}{|c|}{ Second-growth forest restoration } \\
\hline $50 \%$ acres & 142.55 & 39.58 & 0.000 & $32,366,500$ & $23,378,400$ & $41,354,600$ \\
\hline $100 \%$ acres & 97.16 & 32.29 & 0.003 & $22,061,300$ & $14,730,300$ & $29,392,300$ \\
\hline \multicolumn{7}{|l|}{ Program-specific } \\
\hline $50 \%$ all attributes & 416.11 & 84.95 & 0.000 & $94,481,600$ & $75,192,000$ & $113,771,300$ \\
\hline $100 \%$ all attribute & 380.79 & 83.80 & 0.000 & $86,462,800$ & $67,434,800$ & $105,490,800$ \\
\hline
\end{tabular}

${ }^{\dagger}$ Estimated based on delta method using NLOGIT 4 (Greene 2007).

"Sample mWTP estimates extrapolated to 252,290 total Alaskan households, reduced by the percent (10) of poverty level households (U.S. Census Bureau 2010).

The coefficients on all alternative-specific attributes are significant at $1 \%$ and have appropriate signs. Specifically, the coefficient on cost (representing one-time household contribution to finance the proposed improvements over the status quo) is negative. All else equal, alternatives with higher cost are less likely to be chosen because higher cost reduces utility. The coefficients on all noncost attributes including old growth conservation, watershed restoration, and second-growth forest restoration are positive. This suggests that an increase in preservation and restoration activities increases household utility and that there is a strong preference for the proposed alternatives. Capturing preference heterogeneity among Alaskan households, all the standard deviations associated with the random parameters are highly significant, meaning there are important differences among Alaskan households in terms of their valuations for the different levels of preservation and restoration activities. Specifically, men, those aged less than 45 years, residents of Southeast Alaska, with annual household incomes of less 50,000 dollars, and those with dependents less than 18 years revealed status quo bias.

\section{Mean marginal willingness to pay for conservation}

The estimated coefficients were used to determine Alaskans' marginal willingness to pay (or implicit prices) for improvement in each attribute according to Equation 8. The results (reported in Table 4) show that a typical Alaskan household is willing to pay $\$ 147$ to preserve $50 \%$ of the old growth scheduled for harvest in the Tongass, and $\$ 154$ to preserve $100 \%$ of the old growth scheduled for harvest, thus implying diminishing marginal utility for higher levels of the attribute. The corresponding willingness to pay estimates for restoring $50 \%$ and $100 \%$ of the prioritized degraded salmon streams are \$127 and \$130, exhibiting a similar valuation behavior as for the old-growth preservation attribute. In contrast, WTP for restoring 50\% and $100 \%$ of the prioritized second-growth forest acres are respectively \$143 and \$97. Clearly, levels of the second-growth forest restoration are viewed differently. The estimated marginal willingness to pay for a $50 \%$ increase in all three attributes (program low) is $\$ 416$ per household whereas for a $100 \%$ increase in all attributes (program high) it is \$381 according to Equation 9.

\section{DISCUSSION AND CONCLUSIONS}

The objective of this study was to use best practices for designing a choice experiment most applicable for forest planning and management to measure WTP for conservation programs on the Tongass. The mean WTP for 50\% old-growth preservation (US\$147 2012) is consistent with the mean preservation values found in a meta-analysis (Hjerpe et al. 2015) of global ecosystem conservation(US\$131 2010). Estimation results based on random parameter logit show that household WTP varies depending on the attribute and specific level. However, there are important differences in how respondents value different levels of each attribute. In particular, the scope effect seems to hold for oldgrowth preservation and watershed restoration attributes (with the $100 \%$ level preferred more than $50 \%$ level), but does not for the second-growth forest restoration attribute. For this attribute the coefficient on $100 \%$ is much smaller than the corresponding coefficient on $50 \%$ level. This valuation pattern suggests that Alaskans hold significant values for nontimber outputs because the background information provided to them on old growth preservation explicitly stated that the benefits would be of nontimber type and would entail the loss of timbering jobs on these acres. Yet, the smaller program WTP for a $100 \%$ increase in all noncost attributes compared with a 50\% means that Alaskans' support for conservation has a threshold and is diminished past a certain point.

\section{Implications for forest management}

Because the majority of economic values associated with conservation alternatives on public forests do not exclude others from holding those values (nonrivalry goods), using a regional accounting stance would be too narrow to reflect the benefits and costs to all U.S. citizens, and will seriously misrepresent changes in economic well-being. Some may even consider the U.S. as too 
narrow, and would prefer using a much larger region for accounting because the Tongass accounts for approximately onethird of the world's coastal temperate rainforests (DellaSala et al. 2011). In a study focused on willingness to pay to remove dams to restore salmon populations in Washington, Loomis (1996) found that the rest of the U.S. households reflected $97 \%$ of the benefits. In another study, Pate and Loomis (1997) found that WTP for wetland improvements would be undervalued by $\$ 300$ million if limited to the political boundaries represented by the study site. Thus, for old-growth conservation for which a significant majority of U.S. citizens hold passive use values, extrapolating the willingness to pay estimates of the current research to the U.S. level might be justifiable, although the passive use values held by nonresidents may not be the same as held by the locals. For example, Loomis and Gonzalez-Caban (1996) report that nonresidents willingness to pay for protecting California old-growth forests from fires declined by $1 \%$ for each 1000 mile increase.

Because we do not know how the values change outside of our sample, we conservatively extrapolate WTP estimates to the state of Alaska only, understanding that this underestimates total economic value as national WTP for Tongass conservation is certainly greater than zero. Extrapolation to the state level should be the least contentious because the sample was state-wide, the forest is located here, and the forest benefits state residents in numerous ways. However, sample selection bias must be examined and socio-demographic information from survey respondents indicated that our sample is fairly representative of values for the entire state of Alaska. We also reduced the extrapolation by $10 \%$, the level of Alaskan households living below the poverty level. We think households below the poverty line should not be included in aggregation because they have no discretionary income and because our sample had higher mean income (\$99K) as compared to statewide mean household income ( $\$ 87 \mathrm{~K})$. Given the total number of 252,290 Alaska households (U.S. Census Bureau 2010) minus $10 \%$, the state level estimate of marginal willingness to pay for a $50 \%$ improvement in each of the three attributes is $\$ 94.5$ million, with a range $\$ 75.2$ to $\$ 113.8$ million (Table 4).

Economic efficiency analysis at the forest level, as determined by benefit-cost analysis, has been the guiding economic information used to decide management alternatives and is the place to incorporate TEV estimates of conservation programs. Although managers are not bound to choose the alternative that is deemed most efficient (highest BCA ratio), economic efficiency analysis is a major determinant of land use and is required by the National Forest Management Act of 1976. USFS regional economic efficiency has generally compared revenues (benefits) from timber, minerals, and recreation to the agency costs of providing these revenues. Traditionally, this has boiled down to comparing stumpage receipts to the cost of timber sale preparation and administration. Timber, mineral, and recreation revenues are easily tracked and are emblematic of the use-values dominating national forest economic efficiency analysis. Lesser known, and perhaps more difficult to quantify, are the numerous indirect use values held for supporting ecosystem services and the passive use values that are affected by the type of management strategy pursued. For example, what is the reduction in public passive use values per additional scheduled acre of old-growth harvest? What is the increase in value for scheduled conservation programs?
Analyzing the benefits and costs of the Tongass old-growth timber sale program illustrates that beyond being the last industrial scale old-growth logging in the U.S., the Tongass is also the most socially inefficient timber program in the U.S. Stumpage receipts, or benefits, to the U.S. treasury on the Tongass have a base rate of $\$ 7.12 / \mathrm{mbf}$ (thousand board feet) as compared to correlating agency costs to produce timber sales of $\$ 101 / \mathrm{mbf}$ (TLMP 2008:3-546), costs exceeding benefits by a ratio of 14 . The extremely low stumpage for Tongass timber is a result of the exorbitant costs of timber production in remote Southeast Alaska (Crone 2005). The economic inefficiency of the Tongass timber program becomes even greater when incorporating the opportunity costs of lost societal welfare determined in this study. Dividing the extrapolated mean marginal WTP determined for the $50 \%$ old-growth conservation attribute from Table 3 in this study ( $\$ 33.3$ million) by the acres for that attribute $(222,500)$ reveals an average marginal willingness to pay of $\$ 150$ per acre of conserved old growth. At a finer scale, using an average sawlog volume for Tongass timber stands of 20mbf/acre (TLMP 2008:3-327), the economic demand for conserving Tongass old growth currently scheduled for harvest is approximately $\$ 7.50$ / mbf. Thus, the economic value to society foregone by scheduling Tongass old-growth timber for harvest is, by itself, greater than the stumpage received for this timber. When adding this opportunity cost to the agency cost of planning timber sales, costs exceed benefits by a ratio of 15 . This opportunity cost associated with lost welfare values when scheduling old growth timber for harvest can be directly calculated for each management alternative based on the proposed acres of old growth scheduled for harvest.

\section{Recommendations for further research}

Greater inclusion of nonmarket ecosystem service values in public forest planning, as related to conservation or exploitation of resources, faces institutional and methodological barriers. We have identified many of these and have recommended best practices for designing conservation valuation studies that are applicable to public forest planning. While the economics profession may not have much influence on reducing the institutional barriers, economists can, and need, to improve their valuation methods to provide greater application of results to public lands management. Improving the applicability of conservation valuation is a difficult task and will require more deliberate approaches in experiment design and pretesting. Environmental improvements associated with conservation can be defined and articulated in numerous ways, making commodity heterogeneity a significant issue for applicability (Van Houtven et al. 2007). Based on our case study, we see a need for further research on streamlining choice models so as to be in greater alignment with public land management units and outputs, providing for more valuable secondary information beyond just final WTP estimates, determining the spatial extent of values for extrapolation, and improved packaging of attributes and alternatives so as to be bundling flows of ecosystem services in similar directions.

Discrete choice analysis, as used in this study, primarily focuses on a household's most preferred alternative. Information on the next best choices of a household is lost. Contingent ranking analysis that uses information on the most preferred options as well as second and third preferred options would be helpful to gain insights into the intensity of Alaskans feelings toward the 
proposed management alternatives. Research on the role of attitudes and opinions and the underlying rationale would also be helpful. In particular, researching how the relative significance of various types of values (use versus passive use) changes spatially, across socio-demographic groups, and across stakeholders (e.g., forest industry, loggers) would help policy makers in honing implementation of the proposed management alternatives.

[1] We use the term "old growth" to represent all stands not impacted by industrial-scale logging and do not consider an arbitrary tree age. These natural forest stands are typified by mature forests, but include patches of various aged trees that have been naturally regenerated by disturbance.

${ }^{[2]}$ Unproductive forests are defined by the U.S. Forest Service as forests incapable of growing at least 20 cubic feet of industrial wood per acre per year.

[3] This recommendation can be at odds with landscape approaches to valuation because ecosystem boundaries are different in shape, size, and function as compared with administrative and political boundaries. Valuations conducted on small administrative units might benefit from restricting attributes to unique management units.

Responses to this article can be read online at: http://www.ecologyandsociety.org/issues/responses. $\mathrm{php} / 8122$

\section{Acknowledgments:}

We are very grateful for suggestions and comments from anonymous reviewers and journal editors. We would like to acknowledge input on choice design from William Greene, Warren Kuhfeld, Wendy Loya, Ian Munn and maps from Jason Leppi and Melanie Smith. Additionally, we thank Omkar Joshi, Spencer Phillips, and Nicole Whittington-Evans.

\section{LITERATURE CITED}

Adamowicz, W., P. Boxall, M. Williams, and J. Louviere. 1998. Stated preference approaches for measuring passive use values: choice experiments and contingent valuation. American Journal of Agriculture Economics 80:64-75. http://dx.doi.org/10.2307/3180269

Alaback, P. B. 1982. Dynamics of understory biomass in Sitka spruce-western hemlock forests of southeast Alaska. Ecology 63 (6):1932-1948. http://dx.doi.org/10.2307/1940131

Arrow, K., R. Solow, P. R. Portney, E. E. Leamer, R. Ragner, and H. Schuman. 1993. Report to the NOAA panel on contingent valuation. U.S. Federal Register 58:4602-4614.

Bann, C. 2002. An overview of valuation techniques: advantages and limitations. ASEAN Biodiversity (April-June):8-16.

Banzhaf, H. S. 2010. Economics at the fringe: non-market valuation studies and their role in land use plans in the United States. Journal of Environmental Management 91(3):592-602. http://dx.doi.org/10.1016/j.jenvman.2009.10.003
Ben-Akiva, M., and S. R. Lerman. 1985. Discrete choice analysis: theory and application to travel demand. The MIT Press, Cambridge, Massachusetts, USA.

Bowes, M. D., and J. V. Krutilla. 1989. Multiple-use management: the economics of public forestlands. Routledge, Washington, D.C., USA.

Boxall, P. C., W. L. Adamowicz, J. Swait, M. Williams, and J. Louviere. 1996. A comparison of stated preference methods for environmental valuation. Ecological Economics 18(3):243-253. http://dx.doi.org/10.1016/0921-8009(96)00039-0

Boyle, K. J. 2003. Contingent valuation in practice. Pages 111-169 in P. A. Champ, K. J. Boyle, and T. C. Brown, editors. A primer on nonmarket valuation. Volume 3. Kluwer Academic, Dordrecht, The Netherlands. http://dx.doi.org/10.1007/978-94-007-0826-6 5

Christensen, B. 2012. Forest restoration in the Tongass: why, how and where. Technical report prepared for The Wilderness Society, Anchorage, Alaska, USA.

Ciriacy-Wantrup, S. V. 1952. Resource conservation: economics and policies. University of California Press, Berkeley, California, USA.

Cotter, P., and M. Kirchoff. 2007. Marbled Murrelet. Chapter 7.3 in J. W. Schoen and E. Dovichin, editors. The coastal forests and mountains ecoregion of Southeastern Alaska and the Tongass National Forest. Audubon Alaska and The Nature Conservancy, Anchorage, Alaska, USA.

Crone, L. K. 2005. Southeast Alaska economics: a resourceabundant region competing in a global marketplace. Landscape and Urban Planning 72(1-3):215-233. http://dx.doi.org/10.1016/j. landurbplan.2004.09.019

DellaSala, D. A., F. Moola, P. Alaback, P. C. Paquet, J. W. Schoen, and R. F. Noss. 2011. Temperate and boreal rainforests of the Pacific Coast of North America. Pages 42-81 in D. A. DellaSala, editor. Temperate and boreal rainforests of the world: ecology and conservation. Island Press, Washington, D.C., USA. http://dx.doi. org/10.5822/978-1-61091-008-8_2

de Steiguer, J. E., L. Liberti, A. Schuler, and B. Hansen. 2003. Multi-criteria decision models for forestry and natural resources management: an annotated bibliography. GTR NE-307. U.S. Forest Service, Northeastern Research Station, Newtown Square, Pennsylvania, USA.

Dunlap, R. 1997. Summary of the 1997 fish habitat risk assessment panel. Appendix 1 in Charles G. Shaw IIII. Use of risk assessment panels during revision of the Tongass Land and Resource Management Plan. General Technical Report PNW-GTR-460. U.S. Forest Service, Pacific Northwest Research Station, Portland, Oregon, USA.

Flatten, C., K. Titus, and R. B. Lowell. 2001. Northern Goshawk monitoring, population ecology and diet on the Tongass National Forest. Alaska Department of Fish and Game, Division of Wildlife Conservation, Juneau, Alaska, USA.

Freeman III, A. M. 2003. The measurement of environmental and resource values: theory and methods. Resources for the Future, Washington, D.C., USA. 
Garber-Yonts, B., J. Kerkvliet, and R. Johnson. 2004. Public values for biodiversity conservation policies in the Oregon coast range. Forest Science 50:589-602.

Gomi, T., R. C. Sidle, and D. N. Swanston. 2004. Hydrogeomorphic linkages of sediment transport in headwater streams, Maybeso Experimental Forest, Southeast Alaska. Hydrological Processes 18:667-683. http://dx.doi.org/10.1002/ hyp. 1366

Greene, W. H. 2007. NLOGIT 4.0. Econometric Software, Inc., Plainview, New York, USA.

Greene, W. H. 2008. Econometric analysis. Sixth edition. Pearson International, New York, New York, USA.

Hanley, N., D. MacMillan, R. E. Wright, C. Bullock, I. Simpson, D. Parsisson, and B. Crabtree. 1998. Contingent valuation versus choice experiments: estimating the benefits of environmentally sensitive areas in Scotland. Journal of Agricultural Economics 49 (1):1-15. http://dx.doi.org/10.1111/j.1477-9552.1998.tb01248.x

Harris, A. 1999. Wind in the forests of southeast Alaska and guides for reducing damage. PNW-GTR-244. U.S. Forest Service, Pacific Northwest Research Station, Portland, Oregon, USA.

Hausman, J. A., editor. 1993. Contingent valuation: a critical assessment. Elsevier, Amsterdam, The Netherlands. http://dx.doi. org/10.1108/s0573-8555(1993)220

Heal, G. M., E. B. Barbier, K. J. Boyle, A. P. Covich, S. P. Gloss, C. H. Hershner, J. P. Hoehn, C. M. Pringle, S. Polasky, K. Segerson, and K. Shrader-Frechette. 2005. Valuing ecosystem services: toward better environmental decision-making. National Academies Press, Washington, D.C., USA.

Heifetz, J., M. L. Murphy, and K. V. Koski. 1986. Effects of logging on winter habitat of juvenile salmonids in Alaskan streams. North American Journal of Fisheries Management 6 (1):52-58. http://dx.doi.org/10.1577/1548-8659(1986)6<52:eolowh>2.0. $\mathrm{co} ; 2$

Hensher, D. A., J. M. Rose, and W. H. Greene. 2005. Applied choice analysis. Cambridge University Press, New York, New York, USA. http://dx.doi.org/10.1017/CBO9780511610356

Hjerpe, E. 2011. Seeing the Tongass for the trees: the economics of transitioning to sustainable forest management. Economic analysis. The Wilderness Society, Washington, D.C., USA.

Hjerpe, E., A. Hussain, and S. Phillips. 2015. Valuing type and scope of ecosystem conservation: a meta-analysis. Journal of Forest Economics 21(1):32-50. http://dx.doi.org/10.1016/j. ife.2014.12.001

Holmes, T. P., and W. L. Adamowicz. 2003. Attribute-based methods. Pages 171-219 in P. A. Champ, K. J. Boyle, and T. C. Brown, editors. A primer on nonmarket valuation. Volume 3. Kluwer Academic, Dordrecht, The Netherlands. http://dx.doi. org/10.1007/978-94-007-0826-6_6

Holmes, T. P., J. C. Bergstrom, E. Huszar, S. B. Kask, and F. Orr III. 2004. Contingent valuation, net marginal benefits, and the scale of riparian ecosystem restoration. Ecological Economics 49 (1):19-30. http://dx.doi.org/10.1016/j.ecolecon.2003.10.015

Keeley, E., P. Slaney, and D. Zaldokas. 1996. Estimates of production benefits for salmonid fishes from stream restoration initiatives. Watershed Restoration Management Report No. 4. Ministry of Environment, Lands and Parks, and Ministry of Forests, Victoria, British Columbia, Canada.

Kirchoff, M. D., and J. W. Schoen. 1987. Forest cover and snow: implications for deer habitat in Southeast Alaska. Journal of Wildlife Management 51(1):28-33. http://dx.doi.org/10.2307/3801623

Kline, J. D., M. J. Mazzotta, T. A. Spies, and M. E. Harmon. 2013. Applying the ecosystem services concept to public land management. Agricultural and Resource Economics Review 42 (1):139-158.

Krutilla, J. V. 1967. Conservation reconsidered. American Economic Review 57:777-786.

Lehtonen, E., J. Kuuluvainen, E. Pouta, M. Rekola, and C. Z. Li. 2003. Non-market benefits of forest conservation in Southern Finland. Environmental Policy and Science 6:195-204. http://dx. doi.org/10.1016/S1462-9011(03)00035-2

Leighty, W. W., S. P. Hamburg, and J. Caouette. 2006. Effects of management on carbon sequestration in forest biomass in Southeast Alaska. Ecosystems 9:1051-1065. http://dx.doi. org/10.1007/s10021-005-0028-3

Loomis, J. B. 1987. Economic efficiency analysis, bureaucrats, and budgets: a test of hypotheses. Western Journal of Agricultural Economics 12:27-34.

Loomis, J. B. 1996. How large is the extent of the market for public goods: evidence from a nationwide contingent valuation survey. Applied Economics 28:779-782. http://dx.doi.org/10.1080/00036$\underline{8496328209}$

Loomis, J. B. 2000. Economic values of wilderness recreation and passive use: what we think we know at the beginning of the $21 \mathrm{st}$ century. Pages 5-13 in S. F. McCool, D. N. Cole, W. T. Borrie, and J. O'Loughlin, editors. Wilderness science in a time of change: Volume 2: wilderness within the context of larger systems. RMRSP-15-VOL-2. U.S. Forest Service, Rocky Mountain Research Station, Fort Collins, Colorado, USA.

Loomis, J. 2012. Ways to make stated preference methods more valuable to public land managers. Western Economics Forum 11 (1):22-29.

Loomis, J. B., and A. Gonzalez-Caban. 1996. The importance of the market area determination for estimating aggregate benefits of public goods: testing differences in resident and nonresident willingness to pay. Agricultural and Resource Economics Review 25:161-169.

Loomis, J. B., and R. Walsh. 1992. Future economic values of wilderness. Pages in C. Payne, J. M. Bowker, and P. C. Reed, editors. The economic value of wilderness. GTR SE-78. U.S. Forest Service, Southeastern Forest Experiment Station, Asheville, North Carolina, USA.

Loomis, J. B., and D. S. White. 1996. Economic benefits of rare and endangered species: summary and meta-analysis. Ecological Economics 18(3):197-206. http://dx.doi.org/10.1016/0921-8009 (96)00029-8

Louviere, J. J., D. A. Hensher, and J. D. Swait. 2000. Stated choice methods: analysis and application. Cambridge University Press, New York, New York, USA. http://dx.doi.org/10.1017/ cbo9780511753831 
Luyssaert, S., E.-D. Schulze, A. Börner, A. Knohl, D. Hessenmöller, B. E. Law, P. Ciais, and J. Grace. 2008. Old-growth forests as global carbon sinks. Nature 455(7210):213-215. http:// dx.doi.org/10.1038/nature07276

McFadden, D. 1974. Conditional logit analysis of qualitative choice behavior. Pages 105-142 in P. Zarembka, editor. Frontiers in econometrics. Academic Press, New York, New York, USA.

Meyerhoff, J., U. Liebe, and V. Hartje. 2009. Benefits of biodiversity enhancement of nature-oriented silviculture: evidence from two choice experiments in Germany. Journal of Forest Economics 15:37-58. http://dx.doi.org/10.1016/j.jfe.2008.03.003

Mitchell, R. C., and R. T. Carson. 1989. Using surveys to value public goods: the contingent valuation method. Resources for the Future, Washington, D.C., USA.

Morton, P. 1999. Economic benefits of wilderness: theory and practice. Denver University Law Review 76.

O'Toole, R. 1988. Reforming the forest service. Island Press, Washington, D.C., USA.

Pate, J., and J. Loomis. 1997. The effect of distance on willingness to pay values: a case study of wetlands and salmon in California. Ecological Economics 20(3):199-207. http://dx.doi.org/10.1016/ $\underline{\mathrm{s} 0921-8009(96) 00080-8}$

Person, D., M. Kirchhoff, V. Van Ballenberghe, G. Jverson, and E. Grossman. 1996. The Alexander Archipelago wolf: a conservation assessment. PNW-GTR-384. U.S. Forest Service, Pacific Northwest Research Station, Portland, Oregon, USA.

Robertson, G. C. 2003. A test of the economic base hypothesis in the small forest communities of southeast Alaska. PNWGTR-592. U.S. Forest Service, Pacific Northwest Research Station, Portland, Oregon, USA.

Rolfe, J., J. Bennett, and J. Louviere. 2000. Choice modelling and its potential application to tropical rainforest preservation. Ecological Economics 35:289-302. http://dx.doi.org/10.1016/ $\underline{\text { S0921-8009(00)00201-9 }}$

Sabatier, P. A., J. Loomis, and C. McCarthy. 1995. Hierarchical controls, professional norms, local constituencies, and budget maximization: an analysis of U.S. Forest Service planning decisions. American Journal of Political Science 39:204-242. http://dx.doi.org/10.2307/2111764

Spies, T. A., and S. L. Duncan. 2009. Old growth in a new world: a Pacific Northwest icon reexamined. Island Press, Washington, D.C., USA.

Stillwater Sciences. 2012. Forest management and coho salmon population dynamics in Southeast Alaska's Staney Creek watershed. Stillwater Sciences, Portland, Oregon and The Wilderness Society, Anchorage, Alaska, USA.

Thomas, J. W., L. F. Ruggiero, R. W. Mannan, J. W. Schoen, and R. A. Lincia. 1988. Management and conservation of old-growth forests in the United States. Wildlife Society Bulletin 16:252-262.

Tiegs, S. D., D. T. Chaloner, P. Levi, J. Rüegg, J. L. Tank, and G. A. Lambert. 2008. Timber harvest transforms ecological roles of salmon in southeast Alaska rainforest streams. Ecological Applications 18(1):4-11. http://dx.doi.org/10.1890/07-0655.1
Tongass Land Management Plan (TLMP). 2008. Tongass land and resource management plan: final environmental impact statement plan amendment. United States Department of Agriculture, Washington, D.C., USA.

U.S. Census Bureau. 2010. Community facts: selected economic characteristics U.S. Census Bureau, Washington, D.C., USA. [online] URL: http://factfinder.census.gov/faces/tableservices/jsf/ pages/productview.xhtml?src $=\mathrm{CF}$

U.S. Department of Agriculture (USDA) News Release. 2010. USDA Pursues jobs, community stability while developing new approach to forest management in Southeast Alaska. No. 0288.10. USDA, Washington, D.C., USA.

U.S. Forest Service (USFS). 2006. Investing in habitat improvements vital for ecological sustainability, local economies, subsistence users. Alaska Region Newsletter, June.

Van Houtven, G., J. Powers, and S. K. Pattanayak. 2007. Valuing water quality improvements in the United States using metaanalysis: Is the glass half-full or half-empty for national policy analysis? Resource and Energy Economics 29(3):206-228. http:// dx.doi.org/10.1016/j.reseneeco.2007.01.002

Wallmo, O., and J. Schoen. 1980. Response of deer to secondary forest succession in southeast. Forest Science 26(3):448-462.

Walsh, R. G., R. D. Bjonback, R. A. Aiken, and D. H. Rosenthal. 1990. Estimating the public benefits of protecting forest quality. Journal of Environmental Management 30(2):175-189. http://dx. doi.org/10.1016/0301-4797(90)90014-n

Weisbrod, B. A. 1964. Collective-consumption services of individual-consumption goods. Quarterly Journal of Economics 78(3):471-477. http://dx.doi.org/10.2307/1879478 
Appendix 1. Sample choice set used in the analysis of Alaskans' willingness to pay for conservation programs in the Tongass National Forest.

QUESTION 1. Consider the three plans shown below are the only options available to manage the Tongass National Forest, whereby:

Alternate PLAN A will: restore 100\% of degraded streams miles, 50\% of second growth acres, conserve $100 \%$ of old growth acres scheduled for harvest, and cost $\$ 150$.

Alternate PLAN B will: restore $100 \%$ of second growth acres and cost $\$ 30$.

The Current PLAN will: restore 5\% of degraded stream miles, $1 \%$ of second growth acres, conserve $0 \%$ of old growth acres scheduled for harvest, and cost $\$ 0$.

Please Answer QUESTION 1 and QUESTION 2 below.

\begin{tabular}{|c|c|c|c|}
\hline Attribute & PLAN A & PLAN B & Current PLAN \\
\hline $\begin{array}{l}\text { Watershed restoration (\% of stream miles to be } \\
\text { restored out of } 100 \text { miles) }\end{array}$ & $100 \%$ & $0 \%$ & $5 \%$ \\
\hline $\begin{array}{l}\text { Forest restoration (\% of second growth acres to be } \\
\text { restored out of } 100,000 \text { acres) }\end{array}$ & $50 \%$ & $100 \%$ & $1 \%$ \\
\hline $\begin{array}{l}\text { Old growth conservation (\% of acres to be conserved } \\
\text { out of } 445,000 \text { acres) }\end{array}$ & $100 \%$ & $0 \%$ & $0 \%$ \\
\hline $\begin{array}{l}\text { One time contribution to Tongass restoration and } \\
\text { conservation fund ( } \$ \text { cost to your household) }\end{array}$ & $\$ 150$ & $\$ 30$ & $\$ 0$ \\
\hline
\end{tabular}

QUESTION 1. Please Check your most preferred PLAN (Choose only one PLAN from the three).

\begin{tabular}{l|l|l|l}
\hline mans & $\square$ & $\square$ & $\square$ \\
\hline
\end{tabular}

QUESTION 2. Please Check your next most preferred PLAN (Choose only one PLAN from the remaining two)

\begin{tabular}{l|c|c|c}
\hline . \\
\hline
\end{tabular}

